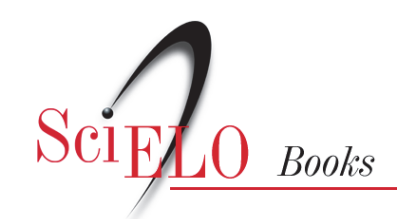

\title{
Seduepb
}

Gênero, sexualidade e cultura: uma agenda contemporânea.

Perfis das personagens mulheres da literatura brasileira de autoria feminina: dependência, vingança, solidão

\author{
Antonio de Pádua Dias da Silva
}

SciELO Books / SciELO Livros / SciELO Libros

MACHADO, CJS., SANTIAGO, IMFL., and NUNES, MLS., orgs. Gêneros e práticas culturais: desafios históricos e saberes interdisciplinares [online]. Campina Grande: EDUEPB, 2010. 256 p.

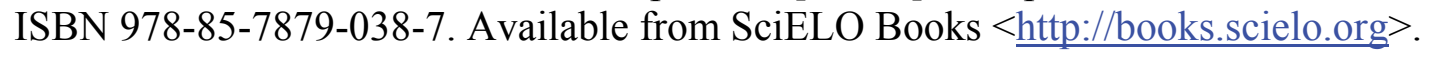

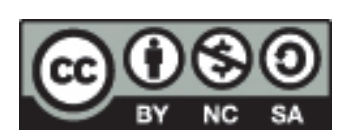

All the contents of this work, except where otherwise noted, is licensed under a Creative Commons Attribution-Non Commercial-ShareAlike 3.0 Unported.

Todo o conteúdo deste trabalho, exceto quando houver ressalva, é publicado sob a licença Creative Commons Atribuição Uso Não Comercial - Partilha nos Mesmos Termos 3.0 Não adaptada.

Todo el contenido de esta obra, excepto donde se indique lo contrario, está bajo licencia de la licencia Creative Commons Reconocimento-NoComercial-CompartirIgual 3.0 Unported. 
Gênero, sexualidade e cultura: uma agenda contemporânea 


\section{Perfis das personagens mulheres da literatura brasileira de autoria feminina: dependência, vingança, solidão}

\section{Antonio de Pádua Dias da Silva}

Os estudos sobre a representação de mulheres na literatura construíram uma vasta fortuna crítica em torno desse tema. Numa primeira visada, percebe-se um discurso erigido sobre personagens mulheres que desestabilizaram, segundo as leituras feitas, no plano do tecido literário, estruturas dominantes de poder, calcadas na ordem patriarcal e falocêntrica. Em outro momento, é a imagem de personagens mulheres que não se libertam das amarras patriarcais e machistas e atuam, na estrutura narrativa, como actantes que têm um papel predeterminado a desempenhar e não se importam com as consequências ou sequelas da relação de sujeitamento a que se impõem, uma vez que agem, segundo já foi afirmado, como indivíduos vinculados a uma ordem que estabelece papéis de gênero fixos, quase imutáveis, impedindo, assim, uma discussão em torno daquilo que faz as mulheres, na representação, serem interpretadas o mais negativamente possível.

O objetivo deste artigo é analisar aspectos psíquicos, através da leitura do comportamento, de falas e de atitudes, de personagens mulheres da literatura brasileira contemporânea, centrando-se basicamente na contística de Ivana 
Arruda Leite - Histórias da mulher do fim do século XX (1997), Falo de mulher (2002) e Ao homem que não me quis (2005). Nele, pretendemos traçar um conciso panorama da trajetória das personagens que habitam a ficção dessa escritora que tomamos como referencial na representação de mulheres. À medida que constatarmos os perfis de personagens mulheres da contística dessa autora, perceberemos que o grande vilão da história das "mulheres do fim do século XX" ou das mulheres contemporâneas é a dependência físico-psicológica, que as mantém numa posição de retaguarda, impedindo-as de avançar naquilo que as tornam mais sujeitos de si; que interdita desejos e prazeres, uma vez que se pauta na lógica monogâmica; que cega as mulheres com o intuito de não deixá-las vislumbrar outras perspectivas de vida fora da relação em que estão inseridas; mas que também contribui para, uma vez essa dependência sendo alimentada, proporcionar uma felicidade às personagens mulheres que vivem essa situação, principalmente quando os problemas enfrentados por elas são oriundos de uma plena consciência de ações que resultaram em aspectos negativos como a solidão.

Essas mulheres representadas fazem parte de um universo ficcional paralelo ao universo em que nós, sujeitos humanos "reais", vivemos; por isso há, nessa lógica, aproximações entre o objeto tomado como referencial para a representação e a imagem dele representada pelos filtros particulares de escritoras, especificamente de Ivana Arruda Leite. Quando especifico essa escritora, estou chamando a atenção para o fato de que a mesma representação também está presente em outras autoras que, por questões de tempo e de espaço, não puderam estar aqui sendo discutidas.

Quando pensamos nas personagens que viveram seus dramas no "arquivo" da linguagem, consideramos, por analogia, os dramas que cada uma passa, no universo empírico e em sua particularidade. Ora, a representação literária, assim como toda representação, só é possível em função de uma dada realidade que é absorvida por determinados "sujeitos", filtrada por aspectos particulares e coletivos que vão da visão mais simples de o indivíduo entender a si mesmo à complexa tarefa de incorporar a essa visão aspectos políticos, econômicos, filosóficos, psicológicos, culturais, dentre outros. Isso significa que o drama das personagens aqui estudado estabelece pontes com a realidade oferecida como matriz de existência das fábulas geradas nas obras tomadas como corpo de análise, confirmando-se uma equação lógica no campo da teoria da literatura: uma dada realidade aparente impulsiona a criação de uma dada representação - sem 
esta ser espelho daquela - e esta faz retornar ao mesmo lócus de origem os dramas representados sob outros filtros culturais e psicológicos, interferindo nessa visão representada posições bio-políticas, bio-psíquicas, culturais, religiosas, dentre outras, numa perspectiva particular (a escritora, neste caso, é livre para devanear no processo de escrituração do texto poético-literário) e/ou coletiva (por mais que sejamos livres para assumir certas visões de cunho próprio ou mais íntimo, não negamos que determinadas ações ou comportamentos são internalizados, muitas vezes até inconscientemente, do imaginário coletivo ou, no dizer dos sociólogos e antropólogos, do inconsciente coletivo).

A visão que temos sobre a problemática das mulheres contemporâneas representadas nas imagens das personagens de ficção é uma das mais fiéis visões a que muitos pesquisadores de áreas distintas chegaram como os estudiosos das questões de gênero, da psicologia social, da antropologia e outros: as mulheres representadas experienciam a dolorosa via crucis do existir entre uma estrutura que foi berço de sua pertença e educação e estruturas nascidas da movência dessa base secular, que as conduzem a uma reinterpretação do seu lugar e papel na sociedade. Essa característica do sujeito se pensar entre o uno e o plural, por exemplo, deu base para que rotulássemos tal comportamento de paradoxal ou ambivalente, uma vez que as personagens mulheres aqui referidas movem-se constantemente numa fronteira em processo de redimensionamento, posicionando-se entre o resistir (à Ordem) e o identificar-se (com a Ordem).

A dependência biológica (ao corpo do outro), por alocar-se numa base fisiológica (o sexo), se estende para outros domínios do sujeito, que interferem diretamente na construção política do sujeito mulher, se não num todo, ao menos parcialmente, pois muito do que constitui a estrutura psíquica do indivíduo, pertença ele a que gênero for, tem sua formação em aspectos físicobiológicos, que são interpretados socialmente e cimentados num imaginário cultural que permanece por determinados períodos de tempo ou gerações.

Para as mulheres, nesse caso, diferentemente dos homens que ainda são interpretados à luz de pressupostos culturais de base patriarcal ou falocêntrica, a dependência física parece atingi-las em maior proporção, pois os casos de representação de mulheres "vazias" ou "em busca de preenchimento", sejam elas construídas por escritor homem ou mulher, têm um mesmo tratamento linguístico-literário, são representadas da mesma forma, padecendo da mesma 
falta ancestral de que falam os psicanalistas lacanianos, quando alocam a mulher no campo do "não-marcado", do "não-falo" (GAUDÊNCIO, 2006, p. 11).

Como a análise dessas personagens mulheres que propomos nesse artigo é de base culturalista, a partir da representação literária, tomo o discurso de interpretação da mulher na psicanálise para corroborar uma prática social estabelecida culturalmente nos últimos séculos nas sociedades ocidentais: as mulheres dessas sociedades sofrem do "mal da dependência" do homem, uma vez que historicamente foram educadas a pertencer ao gênero oposto que teve a incumbência de prover o outro (a mulher) da falta que ele sentia, fosse física, intelectual, moral, econômica, política. Ora, assim pensando, o falo preenche a vagina (não esqueçamos a acepção medieval desses órgãos: falo=espada, vagina=bainha da espada, ou seja, a vagina funciona como local de guardar a bainha), o estudo acadêmico-formal do homem supria a "baixa intelectualidade" da mulher, o valor moral que o homem adotava salvaguardava toda a família, os bens que possuía ou o cargo ocupado tinha que sustentar a mulher, a posição que assumia na sociedade, bem como suas ideias eram pensadas por ele em benefício também do seu outro, a mulher.

As sociedades de base patriarcal ou falocêntrica construíram esse mito da dependência da mulher em relação ao homem. Esse discurso foi tão bem articulado em imagens constituintes de nossa herança antropológica, que as estruturas do inconsciente ou imaginário coletivo não foram redimensionadas, ao logo dos últimos séculos, no que tange às questões de gênero. Mesmo vivendo numa época em que os discursos em favor de liberação, emancipação e liberdade das mulheres e demais categorias antes oprimidas pelos homens são constantes e penetram com maior força que em outras épocas nos debates em torno da questão, parte das mulheres ainda continua presa - muitas têm consciência do fato - ao regime da dependência. Não porque os homens a oprimem como antes. Não porque as estruturas sociais as mantêm nesse lugar ou posição. Pelo contrário. As políticas públicas em favor das mulheres demonstram o quanto de respeito e tolerância ao outro são motivos da existência de outros discursos, mais positivos, que exibem os pares sociais em relações de tratamento igual.

A dependência ocorre porque homens e mulheres experienciam uma fase na história da modernidade ocidental que não tinha acontecido em tal proporção: as estruturas que sustentaram as antigas sociedades estão ruindo de 
tal forma e outras estruturas estão surgindo sem bases sólidas de sustentação, que os habitantes dos espaços onde essa "onda" acontece não têm uma causa a defender, um discurso a lhe interpretar, um sistema a que se sujeitar, pois em época de capitalismo tecnológico e de mobilidade de identidades, as formas estruturais que se apresentam para esses indivíduos parecem provisórias, efêmeras, logo, sem raízes, sem uma identidade fixa (a redundância é consciente: por identidade entende-se um discurso que aloca sujeitos numa base sólida e pouco mutável de interpretação).

É possível, por esse ângulo, visualizar e perceber a coexistência de marcas culturais que herdamos do patriarcalismo, nas atuais sociedades, impedindo, de certa forma, a solidificação de uma base de relacionamentos de gênero pautada no entendimento e tolerância do outro, contribuindo-se assim para o que em outro trabalho chamamos de equilíbrio ecológico cultural (SILVA, 2005). Percebe-se que não é possível admitir uma plena experiência emancipatória de mulheres, do ponto de vista bio-político, conforme discurso de Foucault (1994), sem ainda os entraves dessa dependência cultural, que atua determinantemente no imaginário pessoal e coletivo, ordenando, manipulando, interditando, oprimindo.

Escritos como "O pato e a pata", de Falo de mulher, obra de Ivana Arruda Leite, são provas cabais de que a dependência que as personagens mulheres expressam em relação aos homens é de ordem bio-psíquica, ou seja, a introjeção da imagem do objeto de seu afeto interfere no estímulo ao desejo e vive-versa, de forma que não é possível encontrar um ponto de equilíbrio capaz de tornar essas mulheres felizes sem a presença física do objeto desejado.

Eu tenho um pato na geladeira. Se Atílio virá ou não me ver, se voltará com a ex-mulher ou não, se me quer ou não são conjecturas que não vão ao forno [...] Ontem fui dura com ele: se vier é pra sempre, de mala e tudo. Ou então não me apareça nunca mais. O que era doce acabou-se. Tenho medo que o pato não volte nunca mais. (p. 75, itálico nosso)

$\mathrm{O}$ que mais marca essa dependência nas personagens que aparecem nesse cenário ficcional é o fato de elas terem outra mulher com quem dividir o homem de quem gostam, padecer a agonia de vê-lo conscientemente não se furtar ao prazer de ir ao encontro da outra, deixando-as em casa sempre esperando pela volta dele. E o que soa "pior" nessas relações conjugais é a consciência adquirida 
pelas mulheres de que resistir ou enfrentar essa que é uma das práticas culturais da Ordem significa perder como sujeito (mesmo que parcialmente), uma vez que o imaginário masculino adotado por homens que agem como os que habitam essas ficções são resistentes a mudanças, atuam conforme regras préestabelecidas que os colocam numa posição vertical e superior na hierarquia assumida pelos sujeitos dessa relação. Por isso elas não ousam querer propor, conforme canta Alcione, "ou ela ou eu", pois, segundo fala do sujeito da letra cantada, "só não faço a pergunta com medo da falta que você vai fazer". Por medo da perda do outro do seu afeto, no âmbito afetivo-sexual, as mulheres sujeitam-se aos homens. A personagem do escrito em discussão assim conclui a sua vida de eterna esperançosa de que seu homem volte no dia seguinte, depois de ter passado a noite ou os dias anteriores com a ex-mulher:

\footnotetext{
Abro as janelas e fico soletrando feito uma pata sentada no sofá até o dia clarear:

Pe com a, pa.

Pe com é, pé. O pato deu no pé.

Pe com i, pi. Pimenta no cu dos outros é refresco.

Pe com o, pó, tudo virou pó.

Pe com u, puta, que merda de vida. (p. 76)
}

Não resta consolo para essas mulheres a não ser a dura certeza de que a dependência bio-psíquica pode ser um grave entrave para uma "plena emancipação", uma liberação ou uma vida mais tranquila para essas mulheres, ao mesmo tempo em que essa dependência, se encarada de forma consciente como uma das características da forma de amar do feminino (a devastação), nesse caso, pode ser encarada por mulheres como um fato não interferente nas outras esferas de emancipação do feminino. Se o "pato dá no pé"; se "tudo vira pó" na "vida de merda" que ela leva, ela dá uma resposta incisiva: "pimenta no cu dos outros é refresco". O adágio popular diz muito dessa experiência agônica pela qual passam muitas mulheres. Seria muito bom, no dizer popular, que as mulheres pudessem em "alto e bom tom" gritar para todos que o outro do seu afeto teria que escolher entre uma e outra (indivíduos mais radicais nem esperariam por essa opção: ao primeiro sinal de relacionamento extraconjugal por parte de seus/suas companheiros/as acabam o relacionamento com o outro sem direito à discussão ou pedido de desculpas). Todavia, as malhas em que estão enredadas não colaboram, no plano da ficção, para uma relação ou tratamento 
igual entre os gêneros, considerando-se as relações conjugais e extraconjugais de base heterossexual.

Essa dependência explícita não quer dizer sujeição inconsciente. Ao contrário, as personagens mulheres da ficção de Ivana Arruda Leite são conscientes da posição que assumem nas sociedades representadas e por isso são ambivalentes ou paradoxais em suas bases bio-políticas e/ou culturais. $\mathrm{O}$ fato de admitirem a dependência ao homem num caso específico, como o da relação conjugal, não altera muito o projeto de emancipação do sujeito mulher nas culturas de base ocidental, se tomarmos a realidade empírica como modelo de leitura de mulheres. Por isso, mesmo em face do sujeitamento servil ao outro pela dependência bio-psíquica, mantêm consistente a postura de mulheres que nos outros espaços simbólicos e materiais de existência e coexistência com os gêneros atuam de forma mais livre, emancipadas, principalmente porque transgridem ou violam as normas pré-existentes que alocam os gêneros em posições estanques no corpo social, quando não conseguem um diálogo profícuo com os sujeitos do gênero masculino.

Com um forte ar de ferocidade linguística, essas mulheres enfrentam, em outros âmbitos, os sujeitos masculinos e, como seguindo uma lógica ascendente de manutenção ou sustentação de um projeto de autonomia, parecem se vingar dos seus antigos opressores, seja na pessoa, seja no símbolo de pertença dele:

Ele não tinha esse direito. Não depois de tudo que vivemos juntos. Um dia namora comigo, me leva ao cinema, jura eterno amor, no outro diz que não quer mais saber de mim? $\mathrm{E}$ as promessas, os beijos, as juras de amor? Não, isso não se faz, não se brinca assim com mulher. Um belo dia ele toca a campainha, senta-se a minha frente [...] diz que [...] estava tudo terminado [...] eu virei bicho [...] resolvi dar um tempo [...] como se não bastasse, ainda teve a cara de pau de me dizer que namoro é coisa que se termina todo dia [...], quando me apontou a porta da rua $[\ldots .$.$] essa vai ter troco [\ldots]$ dois, três dias de novo fui de novo à sua casa [...] comecei a chutar a porta [...] no jardim havia uma primavera que arranquei com raiz e tudo. Quem disse que primavera não serve pra matar um homem? Taquei a primavera na janela, com toda força. Machuquei minha mão inteira nos espinhos, virou um sangue só. Depois passei a mão suja de sangue na parede branca da casa e manchei tudo de vermelho, de propósito. A primavera não o matou. Ficou lá, enroscada na grade de proteção, toda torta como eu. Mas os vizinhos saberão que aqui mora um homem capaz de fazer uma coisa dessas com uma mulher. (p. 53-55, itálico nosso) 
Como podemos perceber, embora haja toda uma narração da dependência dessa mulher em relação ao homem de quem gosta, uma outra face de seu comportamento, quanto à interpretação do fato, se revela, de modo a ser possível dizer da construção de um outro modelo de mulher que surge no final do século XX e início do século XXI. É a mulher transitória ou em processo de redimensionamento. Ela admite a fraqueza do pertencer psiquicamente ao outro, ao mesmo tempo em que não corrobora as atitudes ainda sob a Ordem antiga que o homem tem para com ela. Tentar resgatar um relacionamento, um amor, uma paixão, como se diz no dia-a-dia, não oferece nenhum perigo ou desvirtua a moral de qualquer sujeito. Pelo contrário, as pessoas deveriam lutar por serem felizes, seja buscando o outro do seu afeto, desgarrado em outras veredas ou extraindo de suas vidas pessoas que só lhe fazem mal, por mais que delas gostem ou sintam nutrir sentimento que ainda as fazem presas a esse outro.

Entretanto, a personagem se comporta não como quem "quer a todo custo" o objeto de prazer, como se estivéssemos diante de um sujeito portador de traços obsessivos. Na luta por manter uma postura coerente com o ideal de mulher do fim do século, falando como mulher ao homem que não lhe quis, avalia toda a performance desse sujeito a quem ela só o presenteou com a cordialidade dos amantes e o enfrenta no espaço dele. Os palavrões, a exposição pública de uma relação íntima soam como uma vingança porque concentram forças no não enfrentamento do outro, que se esconde, que não sai de dentro de casa para enfrentar quem tanto maltratou. A sua vingança não é tê-lo matado, porque não o conseguiu. Consiste em sair do seu antigo pedestal de somente amante e desmascarar o homem de quem gosta, mas que a faz sofrer.

Quer matá-lo. Mas "a primavera” não tem porte suficiente para tal fim. A imagem da primavera - não da flor, mas da estação - nos faz lembrar o conto "O búfalo" de Clarice Lispector. Lá, a personagem rejeitada pelo homem que ama quer matá-lo a todo custo, arrancá-lo de sua vida. Como o ama demais, procura uma forma de vencer o amor, odiando-o, pois só assim poderia "pagar na mesma moeda” o sentimento sentido: a rejeição (às vezes, a indiferença). A saída encontrada é ir ao zoológico, pois lá encontraria feras, animais selvagens, signos, para ela, de sentimentos primitivos e/ou selvagens. Todavia, quando adentra o zoológico, percebe que os animais estão todos enamorados porque é primavera. Assim, não satisfaz seu desejo; pelo contrário, promove, com essa busca, um encontro metafórico com o objeto de desejo na imagem do búfalo, que titula o conto. 
Não só Clarice Lispector escreveu sobre essa mulher do fim do século. Marilene Felinto em Obsceno abandono - amor e perda (2002) alude a mesma situação: mulher rejeitada pelo outro do seu afeto intenta vingar-se do homem que a abandonou:

O segredo é não se emocionar - não se emocionar nunca, não revelar aos outros o que você está sentindo. [...] Ou então matar [...] Uma pessoa não pode enfiar seu sexo, seu dedo, seu membro no sexo da outra e depois ir embora! Vagina é talho aberto: eu sou um sangue, Charles, seu idiota. É uma questão de se rebelar: Pois eu quero que você morra, Charles. Para que passei cinco anos da minha vida nisso? Saio sem nada - uma mão na frente, outra atrás. É uma questão de chamar a isto de obscenidade: uma pessoa não pode enfiar a língua profundamente no sexo da outra um dia (inaugurando gostos, despertando sensações, provocando arrepios de pura vida) e desaparecer depois [...] Eu quero que você vá pro inferno, Charles. De todas as pessoas que não me quiseram, você foi a pior. (p. 30-31)

A imagem da vingança do homem amado, caso queiramos fazer uma cartografia desse desejo perverso, é antiga, vem de tempos míticos. As personagens abandonadas não reagem como as mulheres sob a Ordem. Não misturam o ato de amar com o ato de reivindicar, de buscar os seus direitos, mesmo que essa busca consista no reivindicar o homem que não as quiseram, que as rejeitaram. Outra: um ponto positivo nessa representação é a forma consciente como essas personagens agem, ou seja, longe de terem apenas insights significativos como a personagem Macabéa de $A$ hora da estrela, ou de agirem em conformidade com a Ordem estabelecida, como quase todas as heroínas da literatura clássica, principalmente a literatura de ficção do século XIX e primeira metade do século XX, as personagens aqui em discussão admitem uma vasta consciência do papel que exercem na sociedade, reivindicando seu lugar nas estruturas sociais.

Vera Romariz em Amor aos cinqüenta (2004) traz à tona um poema Sonhos podres - em que o sujeito feminino do texto, consciente de sua posição social nos tempos de hoje, nas sociedades abertas ao tratamento igual entre os gêneros, reivindica um retorno ao viver sob a Ordem preterida, não como forma de submissão consciente, mas expressão da liberdade sentida: de poder optar, inclusive pelo lado mais rejeitado pela vida, conforme poema abaixo: 
Fiz eu mesma o ninho

Onde há tantos anos me aninho

E cometi o mortal pecado de não cometer pecados

Pois de tão madura

Apodreci meus sonhos

Dei a todos o direito estúpido de compreendê-los

E me cansei das bobagens adiadas [...]

Cantando cirandas com voz cansada

Reivindico o direito à dependência

À fragilidade biquinho antigo dengo carinho [...]

Irresponsavelmente filha e neta

Abusarei do direito à dependência

E exigirei banquetes em minha homenagem

Pois cansei de não poder cansar

E de tão madura apodreci meus sonhos (itálico nosso)

O poema, caso fôssemos lê-lo apenas de imediato, poderia trapacear a interpretação, pois à primeira vista ele se nos mostra como corroborando uma prática sóciocultural negada pelas mulheres de hoje: a dependência à Ordem. Na verdade, a mulher que fala no poema, consciente de sua posição no mundo/sociedade, reivindica a sujeição, de forma consciente (lembremo-nos: essa sujeição não é aquela imposta pelo poder do falo). Quer para si a dependência a uma ordem, assim como há mulheres que mesmo diante de práticas emancipatórias e/ou liberadoras, optam pela ocupação das "funções" clássicas de mulher: mãe, dona de casa/trabalhadora do lar, sem que essa opção venha lhe causar perdas ou danos.

Assim se comportam as personagens das autoras aqui citadas, mesmo em face da situação paradoxal em que atuam. As personagens são detentoras de uma autonomia para optarem por papéis que consideram importantes para si. Essa forma de agir se torna importante, no contexto de discussão, porque antigas práticas ainda mantidas por mulheres dessa ficção diferenciam-se da mesma prática vivida por muitas personagens da ficção de outras escritoras. Ivana Arruda Leite dá às personagens mulheres voz resistente, apresenta-as agressivas, transgressoras, às vezes más, sem com isso atribuirlhes papel negativo nessa visão de gênero em que se baseia para construir seus "espaços ficcionais".

Em falo de mulher, dois escritos servem como exemplo para discutir a "impotência" do homem diante das aventuras emancipatórias dessas mulheres. São eles: "Receita para comer homem" e "Foda-se, meu bem". No primeiro, percebemos uma inversão da expressão machista ainda cultivada pelo imaginário 
coletivo masculino - que tem, quase na mesma proporção, adeptos no gênero feminino - "comer mulher". A expressão comer alguém, culturalmente enraizada no repertório do imaginário coletivo do brasileiro, carrega consigo o estigma depreciativo do verbo - comer - por estar associado a uma relação predatória antiquíssima, que remonta às bases primitivas e falocêntricas das sociedades, a uma ação impetrada sobre e contra a mulher que é comida ou "coberta" pelo homem (no imaginário coletivo das relações homoeróticas a expressão conserva o mesmo teor negativo, sendo atribuído valor positivo ao predador, ao que come, ao sujeito ativo, e uma interpretação erroneamente "grosseira" ao sujeito paciente desta relação, “aquele que se deixa comer").

Nesse sentido, podemos dizer que em "Receita para comer o homem amado" temos a inversão dessa lógica porque a mulher dessa relação é quem come. Analisando a expressão do ponto de vista da antropologia cultural, percebe-se que há várias razões para que seja essa uma verdade, e não outras razões ou "mentiras sobre o segundo sexo", como o título de recente obra de Sócrates Nolasco (2006). Ora, na relação boca/vagina-pênis, é a porção rachada, fendida, aberta que absorve literalmente o alimento: não apenas o pênis, que é introduzido e consumido pela "vagina dentada", mas também o próprio líquido espermático é absorvido pela vagina-útero para poder o feminino engendrar uma vida.

$\mathrm{O}$ ato de comer, então, assume uma postura mais violenta ou agressiva ao ser utilizada pela mulher do que quando proferida pela boca do homem, nesse caso específico: a) porque o valor semântico do ato predatório e canibalesco foi questionado e rediscutido ao longo da história e b) porque quando usada pelo homem, a lógica instaurada, por já ser lugar comum, não é estranha aos ouvintes ou interlocutores. Já quando usada na pulsão verbal de uma mulher, pode-se ter: 1) o valor semântico da expressão é recuperado num tempo e num espaço diferenciados, logo a força elocutiva e seu valor semântico adquirem posturas atualizadoras e 2) a lógica do ato, por ser estranha aos interlocutores, tanto para homens quanto para mulheres, parece instaurar uma outra norma, numa proporção inversa ao uso da mesma expressão por sujeitos pertencentes a gêneros diferentes. A expressão só ganha novo sentido ou se atualiza porque funciona através da transgressão, da violência da linguagem, num extremo ato de simplificação de uma estrutura ideal comum: "o feitiço virou-se contra o feiticeiro", ou seja, a expressão de valor cultural negativa usada por homens para se referir a mulheres é, agora, usada numa proporção inversa. 
Já no outro escrito, "Foda-se, meu bem", temos numa frase tão simples uma complexidade cultural sendo dessemiotizada ao ressignificar atores "legais" para falar determinados textos e/ou palavras. Temos, nesse título, o verbo pronominal foder-se cujo sentido linguístico-cultural figura em uma espécie de "campo minado", pois funciona, principalmente em momentos de extrema tensão do sujeito, como uma interjeição "pornográfica" ou de agressivo aspecto erótico (coexiste ao lado de "porra", "puta que pariu", dentre outras), acompanhado do vocativo "meu bem", que figura semanticamente no lado oposto do verbo pronominal, pois a expressão/vocativo “meu bem”, quando não ironicamente, é sempre utilizada, no Brasil, com um sentido positivo, carinhoso, terno.

A personagem mulher desse escrito viveu por um bom tempo ao lado de Paulo que, no seu dizer, "sempre bebeu além da conta. Me batia, me xingava, uma vez furou meu pescoço com canivete. Quando engravidei, jurou mudar de vida, procurar emprego [...] com barrigão de oito meses, eu tinha de sair correndo atrás de ajuda dos vizinhos. Um dia não voltei mais" (NOLASCO, 2006, p. 23). Em um tempo mais tarde, quando já tinha criado a filha com Rubens, seu atual companheiro, encontra o pai biológico de sua filha em estado deplorável: Paulo mendigava e estava à beira da morte. A tensão do escrito inicia-se quando, percebendo que o ex-companheiro morria e ela culpava-se por não lhe dizer detalhes da gravidez, cogita falar para ele da filha que um outro educou. A técnica narrativa - ela narra a história em primeira pessoa - engana, momentaneamente, o leitor, que é induzido, também momentaneamente, a acreditar que ela contará ao seu ex-companheiro que ele é pai de sua filha: "encontrei-o deitado sobre uma maca no meio do corredor. Apertei-lhe a mão e prometi não deixá-lo nunca mais". Ficamos como leitores e portadores de aspectos sentimentais de base judaico-cristã meio comprazidos em vê-la na iminência de revelar o fato ao moribundo. Tal é a nossa surpresa quando, no último parágrafo, lemos a seguinte fala:

Tento reconhecê-lo neste homem de barba feita e banho tomado que morre aos poucos ao meu lado, mas não consigo. De vez em quando, chego perto pra ver se ele respira. Em casa pensam que estou na praia, preferi não contar nada a ninguém. Uma única vez ele me perguntou sobre o filbo que eu esperava. Disse-lhe que abortei. (p. 24, itálico nosso)

A resposta que dá à pergunta feita fecha o escrito, literalmente abortando um plano nascido de uma compaixão perante o outro que tinha a vida sendo 
solta como areia entre os dedos. A vingança dessa mulher é forte a ponto de, mesmo em face da morte/impotência do outro, a), não ser capaz de perdoar atos antigos e b) se culpar momentaneamente não por revelar um segredo (porque não havia segredo na gravidez enquanto estiveram juntos), mas por omitir uma verdade que, segundo o imaginário cristão, poderia ser fonte de alguma transformação benéfica na hora da morte do sujeito. Na morte do ex-companheiro, matou a relação, matou as lembranças, matou no outro o sonho do filho um dia gestado. Na consciência do moribundo, morreu junto com ele a possibilidade de expansão e sobrevivência pelo sêmen(te).

A vingança contra o homem/patriarcalismo se estabelece em outros escritos de Ao bomem que não me quis. "El choclo", por exemplo, conta-nos a curtíssima história de Mercedes:

Mercedes colocou o vestido de cetim, pintou de carmesim os lábios e entrou na escola de tango num gesto grená. Às três da tarde voltou para casa, matou com sete facadas o marido que dormia (ele não tinha bigode) e voltou para exercitar a lição número um. (p. 20)

Esse é o escrito. Curto como o trajeto percorrido até a ação impetrada contra o marido. Foi costume admitido no imaginário coletivo brasileiro, por exemplo, atos extremos de violência contra a mulher, como a morte, a surra de pancadas, caso fosse flagrada em adultério, velha prática herdada da legislação judaica que punia severamente e com a morte por apedrejamento a mulher encontrada nessas condições. Em se tratando do nordeste brasileiro, por exemplo, essa prática não só foi usada como ainda figura no imaginário coletivo desse espaço cultural, mais entre as populações de pouca instrução escolar, alimentando uma vaga de homens que não atualizaram seus valores à luz das novas práticas sociais e leis que regem as atitudes dos indivíduos em sociedade. Por outro ângulo, dizemos que também foi e ainda é costume, e mais uma vez, sem nenhum preconceito social, entre os estratos sociais menos favorecidos, a mulher, como uma das únicas formas de vingança pelas "barbaridades" cometidas contra ela pelo outro do seu afeto, castrar o marido/companheiro, principalmente quando ele dorme, "lavando a honra com sangue", tornando o outro impotente naquilo que o faz detentor do falo: o pênis. Se o que determina o poder simbólico é a protuberância física, extrair do homem essa porção vital é, no imaginário de ambos, homens e mulheres, torná-lo inválido, incapaz, 
impotente não só para gozar do prazer do sexo e gerar filhos, símbolo da virilidade, mas, sobretudo, para torná-lo impotente no campo político-social: um homem castrado é um homem recluso, envergonhado socialmente, logo, incapaz de exercer funções públicas, obrigando-se a ser interpretado do ponto de vista que se interpreta aquela que sempre negou no cotidiano: a mulher. Haveria vingança maior?

As mulheres representadas que optam pela não dependência às estruturas arcaicas do patriarcado, na ficção estudada, passam por dois estágios básicos de existência: o primeiro, já discutido, é a vingança contra o sistema/discurso que a oprimiu, lançando sobre o homem um "esporro" comportamental que varia desde a busca pela igualdade de tratamento no interior do lar (e lá mesmo corrobora para a prática do adultério como forma igualitária de viver a relação de gênero) até o ato mais violento, que culmina com o assassinato do marido/ companheiro. No intervalo entre o "desde a" e o "até o": um campo aberto de lutas. O segundo estágio, que veremos a seguir, diz respeito à solidão. Todas as personagens que violaram o código das relações de gênero pautadas em pressupostos de base patriarcal/falocêntrica, sem exceção, sentem o "sabor" da solidão invadir-lhes o ser, mesmo estando com outro companheiro ao lado.

O escrito "Titila" proporciona como fim de história da personagem homônima com Genaro a resposta vazia que ela tanto busca dele na linha telefônica. Depois de ligar inúmeras vezes para o amante e só receber a mensagem da secretária eletrônica, desiste da busca, aborrecida com a situação. Da situação de dependente e solitária - "Estou tão sozinha" (p. 64) -, passa a de desdenho: "Genaro, olha aqui, se quiser ligar, liga, se não quiser vá pra puta que pariu, não estou nem aí com você. Foda-se cara" (p. 64). Todo o texto deixa clara a situação agônica em que estava vivendo os últimos momentos do dia em que havia ligado para Genaro várias vezes, pedindo para ele preenchê-la, pois estava vazia, sozinha.

"O fim de semana de uma solteirona" é um texto aberto a várias interpretações, pois a sua personagem central, solteirona, passa os finais de semana substituindo a ausência de um corpo de homem pelas "iguarias" que prepara, tornando-se uma mulher obesa, fora dos padrões estéticos que a sociedade exige ou impõe às mulheres. O fato de ter consciência da vida que está levando torna evidente ao leitor que a personagem opta pela situação ou condição em que vive, assumindo, assim, a solidão não como um traço negativo à sua existência 
- embora o título faça alusão a esse aspecto negativo -, mas como parte daquilo que escolheu para si. É bem verdade que a solidão não é um fim escolhido por pessoas “saudáveis", por mais que haja quem opte por, mesmo em situações em que mantenha um relacionamento amoroso, morar sozinho.

Quando dissemos que o escrito em discussão se abre para várias interpretações é porque se pode inferir, também, que o motivo que a leva a engordar com as comidas ingeridas e a vida passiva e sedentária diante da televisão nada mais é do que o próprio sintoma da solidão, muitas vezes tornando a pessoa depressiva, ansiosa. Essa personagem pode, por este ângulo, agir de tal forma em função do que estamos colocando como resultado e não como causa.

Em "Lionete G. Pereira", percebemos um caso de fetiche sexual (o conceito de fetiche é aqui entendido segundo Rosolato (1990) e Peixoto Júnior (1999)), pois a personagem mulher, em sua amarga solidão, devaneia uma relação existente entre ela e o cantor Roberto Carlos, deixando no texto marcas tanto de sua solidão quanto da presença do suposto amante. No momento final da fábula, a personagem, sozinha em seu recanto, num ímpeto fetichista e sonhador, assim se expõe:

Tirou a calcinha e untou as dobras com licor e chocolate. Ele vai adorar. $\mathrm{Na}$ pressa esqueceu a calcinha no escritório. Trancou a porta da cozinha, guardou a chave no bolso e correu para o quarto. Com as faces afogueadas e a boca de cereja e mel, deitou-se na cama. Foi só o tempo de levantar o avental, abrir bem as pernas e mostrar a surpresa ao Roberto Carlos grudado na parede. (p. 88)

O comportamento dessa personagem transita entre várias percepções de um mesmo fenômeno. Optamos por interpretá-lo como o de uma personagem afetada pela solidão, sintoma de que ela é portadora. Para o solitário, principalmente quando esse sujeito pertence ao gênero feminino, comportamentos como depressão, abstinência ou compulsão alimentar, uso de drogas, enclausuramento, fantasias sexuais, por exemplo, são comportamentos diagnosticados a partir de uma simples observação, pois não podemos dizer, do ponto de vista cultural, que a solidão faça bem ao sujeito que vive em sociedade, sobretudo se esse sujeito é um dos que lutam por causas que beneficiariam toda uma "legião" de portadores de uma dada condição, como são as mulheres do fim do século XX representadas nesta ficção. 
Por mais que a solidão seja um dos sintomas do final do século passado e início deste, no dizer de Rojas (1996), era de se esperar que as mulheres portadoras de uma emancipação bio-política não caíssem na armadilha do século em que vivem: uma vez adquirida a autonomia, seria "justo" que procurassem "recuperar" elementos capazes de proporcionar uma solidificação no plano de emancipação delas, de forma que até mesmo a vida solitária pudesse constar como um ato de livre escolha da personagem, sem que com isso tivesse que levar uma vida amarga ou negativamente vazia. Ao contrário desse pensamento, a solidão encontrada nas personagens em estudo deriva ora da dependência que manifestam em relação aos homens que amam e que as negam no cotidiano ora da falta de opção, por não encontrarem uma companhia com quem pudessem, numa proporção igualitária, repartir a vida que o cotidiano oferece, como vemos em "Dulcora", de Ao homem que não me quis:

Nesta rua, em algum apartamento desta rua, em algum quarto deste apartamento, há uma mulher alisando os pêlos, gemendo de amor sozinha. Longe daqui, em alguma outra rua, em outro apartamento dessa mesma rua, em frente a um televisor, há um homem fumando calmamente. Sobre a mesinha, um drops de hortelã pela metade. (p. 10)

Percebe-se que a personagem do escrito citado faz "amor sozinha” em razão do não encontro entre os corpos que foram cooptados, também, pela lógica do capitalismo tecnológico, que torna os lares, principalmente os apartamentos, jaulas em que os moradores assemelham-se a animais presos, escondidos em seus cativeiros para serem expostos apenas no momento da apresentação do show, isto é, são percebidos ou vistos apenas quando saem para, no palco social, atuarem com as máscaras limitadas a que se impuseram. A mulher ali se masturbando sozinha - talvez possamos dizer que por opção - vive um lado cruel da emancipação: o refúgio dos exilados da "antiga corte patriarcal". Enquanto sob a Ordem, estavam seguras de seu homem, de seu futuro, de seu lugar no mundo. Fora dela, a instabilidade se instaura, as certezas fogem por entre as mãos que não conseguem segurá-las. Essa lógica, também, serve para interpretar o homem desse século, que teve suas certezas abaladas e paga um preço muito alto por querer manter-se na Ordem ou por querer dela sair e jogar sob novas regras sociais. A desvantagem para a mulher: ela sempre fora educada para estar ao lado de. É o preceito bíblico: ajudadora, companheira. O 
homem sempre fora educado para estar só, para não necessitar da interferência da mulher em sua vida, pois atuava como provedor, mentor, chefe.

No escrito "Natureza morta", que transcrevemos abaixo, sentimos o peso da solidão da personagem, ou das personagens representadas:

A fruteira sobre a mesa. Dentro, três frutas de cera: vermelha, verde e amarela. Ao redor, duas cadeiras, uma delas vazia. Pela janela, a montanha envelhecida. Mais além, o céu azul. No fundo do vale, duas linhas: uma curva, por onde corre o rio, outra reta, onde tem sempre um trem vindo em minha direção. O trem põe o focinho pra fora, rato imenso, furibundo, ciscando o chão com patas de ferro. Dentro da barriga do trem, um povaréu, o mundo inteiro, menos João. De tanto não vir, João pregou-me nesta paisagem feito um crucifixo. (p. 15, itálico nosso)

O peso da solidão é uma outra responsabilidade com a qual as mulheres emancipadas têm que arcar, assim como tinham que assumir a responsabilidade, sob a Ordem, do peso do buquê. As mulheres urbanas, mesmo as menos escolarizadas, sobrevivem ainda no corpo social à luz da dependência ao homem, sendo, por essa óptica, de certa forma, castigadas (não pelo homem ou pelo discurso do homem) pela opção requerida: a emancipação. Como essa condição ainda não é prática enraizada ou calcificada no imaginário coletivo de muitas das sociedades ocidentais como a brasileira, ainda há muito que discutir e aprender para poder haver uma consolidação dessa nova prática que beneficiou as mulheres por um lado (no lado social, público, por exemplo, foram imensamente beneficiadas com as políticas públicas em favor delas), ao mesmo tempo em que as prejudicou (principalmente no lado pessoal ou afetivo-emocional).

As mulheres dessa "estirpe" são levadas a arcar com as consequências do plano da emancipação. Morar longe dos pais, manter relacionamentos puros (no sentido atribuído por Bauman (2004): sem laços afetivos, apenas relações temporárias), encontrar apenas relações efêmeras, por exemplo, constituem traços comportamentais e escolhas objetivas da nova geração de mulheres, todavia, por não ser uma prática ainda coletivizada de forma equitativa ou homogênea, isto é, por não ser respeitada, tolerada ou até mesmo aceita por todos os membros da sociedade em que atuam, caem na armadilha construída por essa condição: as mulheres emancipadas, na ficção (muitas vezes reflexo da realidade empírica ou aparente), não são cooptadas para o casamento, para o relacionamento duradouro, para a constituição de família, por mais que as relações interpessoais, 
hoje, na realidade empírica, como apontam Bozon (2004) e Heilborn (2004), tenham sido redimensionadas e fogem do modelo tradicional, como visualizamos no escrito "São Cristóvão": "Eu sozinha nesse bar, um pires de azeitona à minha frente e uma cerveja quente pela metade. Largada nesse canto da vida é difícil acreditar que Rodrigo Santoro vai passar aqui e se apaixonar por mim. Mas vai" (p. 19).

Qual a perspectiva para esta mulher "largada nesse canto da vida"? É ter a certeza de que a emancipação traz consigo, assim como todo e qualquer sistema ou estrutura ideológica, certas práticas inevitáveis, certos comportamentos não esperados, determinadas opções negativas e enfrentar a nova condição cultural em que está inserida, sem medo nem culpa? Ou é, somando-se a essa perspectiva, acreditar que a nova condição adquirida pela nova mulher não é condição sine qua non para abortar os sonhos, devanear no cotidiano, continuar a acreditar naquilo que espera, mesmo que o esperado seja um dos mais "tolos" dos sonhos: "acreditar que Rodrigo Santoro vai passar por aqui e se apaixonar por mim"?

Esses questionamentos ainda perdurarão um bom tempo, pois as mulheres representadas na ficção de escritoras brasileiras - e fazemos menção a autoras vivas porque podem ou têm outras condições de representar as mulheres na época em que vivem, talvez no intuito de ver projetado na ficção uma espécie de radiografia dessas novas mulheres - vivem a angústia do retorno à antiga relação estabilizada, segura, protetora, sob a Ordem do Pai, e da tentativa de se encontrarem, de serem felizes em novos condicionamentos construídos para que pudessem exercer o papel que tanto desejaram ao longo de séculos de perseguição (a expressão é do título do livro de Maria Bernadete Alvim de Barros (2001)).

Aprendemos que quando novas práticas culturais, de base político-ideológica, são postas em uso, cria-se toda uma conjuntura de manutenção e responsabilidades não esperadas pelos sujeitos que passam a experienciá-las. É necessário, assim, que tenhamos em mente que o fato de um novo ser estabelecido e trazer consigo problemas aparentes ou de adaptação não é motivo para que retornemos à antiga Ordem, mais segura porque nela nascemos e fomos educados. Isso não significa dizer, também, que as velhas práticas, sejam elas sociais, culturais ou outras, quando diante de novas, têm que se curvar, prestar cerimônia e "desaparecer". Entendemos que o modo patriarcal de existir como sistema de domínio e manutenção de estruturas sociais valorativas prioriza o masculino, não tem condições suficientes de permanecer nas atuais sociedades 
ocidentais, porque verticaliza o pensamento de tal forma que constrói uma longa e pesada hierarquia cujas ordens se movimentam apenas na via de mão única, de cima para baixo, no dizer comum.

Essa prática deve ser combatida porque inferioriza os demais componentes da comunidade, principalmente os não iguais, a saber, as mulheres (não quero pôr em discussão ou demais "outros" das sociedades, como os homossexuais, lésbicas, negros, por exemplo). Por outro lado, também aprendemos que as novas práticas sociais sozinhas não são suficientes para equilibrar a "ecologia cultural" há muito em desarmonia. O novo, neste caso, soa como uma conquista (porque o é) que deve ser vivida ao extremo. Todavia, não nos apercebemos de que o novo quando surge nem sempre é em função da extinção do antigo: pode ser uma espécie de expansão (no caso que estamos tratando não pode ser esta a razão) ou redimensionamento (conforme entendemos que seja). Isso significa dizer que por um bom tempo, antigas práticas estarão em diálogo - daí o paradoxo das personagens entre o resistir e o identificar-se.

Se assim entendemos, algumas das antigas práticas machistas do patriarcalismo bem como as novas práticas oriundas da emancipação do gênero feminino não são suficientes em si para sustentar todo um cabedal ideológico construído historicamente, seja antes ou recentemente. Mas são práticas necessárias ao bom funcionamento da sociedade e do equilíbrio sóciocultural, construindo-se novas propostas a partir das antigas bases, redimensionando o pensamento do homem em contato com essa visão ecológica de manutenção do equilíbrio no campo da cultura. O paradoxo das personagens frente ao antes e o agora provém desse período de adaptação, que esperamos, se assim for o encaminhamento necessário, encontrar bem equilibrado num breve espaço de tempo.

\section{Referências}

BARROS, Maria Nazareth Alvim de. As deusas, as bruxas e a igreja: séculos de perseguição. Rio de Janeiro: Record; Rosa dos Tempos, 2001.

BAUMAN, Zygmunt. Amor líquido: sobre a fragilidade dos laços humanos. Rio de Janeiro: Zahar, 2004.

BOZON, Michel. Sociologia da sexualidade. Rio de Janeiro: Editora FGV, 2004 . 
FELINTO, Marilene. Obsceno abandono: amor e perda. Rio de janeiro: Record, 2002.

FOUCAULT, Michel. Dits et écrits: v. IV. Paris: Gallimard, 1994.

GAUDÊNCIO, Edmundo de Oliveira. Da fala do não-falo: desejo-palavra, silêncio-falta. In: SILVA, Antonio de Pádua Dias da (Org.). Representações de gênero e de sexualidades: inventários diversificados. João Pessoa: Editora Universitária/UFPB, 2006, p. 111-117.

HEILBORN, Maria Luiza (Org.). Família e sexualidade. Rio de Janeiro: Editora FGV, 2004.

LEITE, Ivana Arruda. Ao homem que não me quis. Rio de Janeiro: Agir, 2005 .

Falo de mulher. São Paulo: Ateliê Editorial, 2002.

Histórias da mulher do fim do século. São Paulo: Hackers

Editores, 1997.

NOLASCO, Sócrates. O primeiro sexo e outras mentiras sobre o segundo. Rio de Janeiro: Best Seller, 2006.

PEIXOTO JR. Carlos Augusto. Metamorfoses entre o sexual e o social: uma leitura da teoria psicanalítica sobre a perversão. Rio de Janeiro: Civilização Brasileira, 1999.

ROJAS, Enrique. O homem moderno: a luta contra o vazio. São Paulo: Mandarim, 1996.

ROMARIZ, Vera. Amor aos cinqüenta. Maceió: Edições Catavento, 2004.

ROSOLATO, Guy. Estudos das perversões sexuais a partir do fetichismo. In: CLAVREUL, Jean (org.). O desejo e a perversão. Campinas: Papirus, 1990.

SILVA, Antonio de Pádua Dias da. A moda e o negro nas sociedades ocidentais: por uma lógica positiva de construção e de aquisição de imaginários. In p. $47-66$. (Org.). Imaginários na cultura. Campina Grande: EDUEP, 2005, 